\title{
Relationship between Parental Socio-economic Status and Casual Blood Pressure in Coastal Nigerian Adolescents
}

\author{
Relations entre statut socio-économique et décontractés sang Pression dans la région côtière \\ adolescents nigérians
}

\author{
V. O. Ansa*, M. U. Anah†, F. A. Odey , P. N. Mbu*, E. I. Agbor*
}

\begin{abstract}
BACKGROUND: Emerging data suggest that essential or primary hypertension occurs in the young. Parental socioeconomic status may play a role but the exact mechanisms still remain unclear.

OBJECTIVE: This study was aimed at determining the relationship between parental socioeconomic status and casual blood pressure in adolescents.

METHODS: One thousand and eight adolescents attending two secondary schools in Calabar, Nigeria were selected by stratified random sampling. Their blood pressure, weights and heights were taken using standard methods and sociodemographic data were obtained using a pretested semistructured questionnaire.

RESULTS: Blood pressure was increased with age with males having higher values. The other major determinants of blood pressure were weight, height, body mass index, level of physical activity and parental socioeconomic status $(p<0.05)$. No relationship was established between these determinants as well as dietary habits with parental socioeconomic status ( $p>0.05)$. Female adolescents with parents in the lower socioeconomic classes had significantly higher systolic and diastolic blood pressure $(p<0.05)$. In contrast, parental socioeconomic status showed no significant relationship with systolic blood pressure and diastolic blood pressure in males ( $p>0.05$ ). The prevalence of elevated blood pressure was higher in females than in males.

CONCLUSION: Low parental socioeconomic status appear to be associated with higher casual blood pressure especially in female coastal Nigerian adolescents. Traditional determinants did not appear to play a significant role. Psychological stress arising from environmental and economic stressors may be responsible. WAJM 2010; 29(3): 146-152.
\end{abstract}

Keywords: Parental socioeconomic status, blood pressure, adolescents, Nigeria.

\section{RÉSUMÉ}

CONTEXTE: Les nouvelles données suggèrent que essentielles ou hypertension primaire se produit chez les jeunes. Parental statut socioéconomique peut jouer un rôle, mais les mécanismes exacts demeurent peu claires.

OBJECTIF: Cette étude visait à déterminer la relation entre le statut socioéconomique des parents et occasionnels la pression artérielle chez les adolescents.

METHODES: Les mille et huit adolescents fréquentant deux écoles secondaires à Calabar, au Nigéria ont été sélectionnés par échantillonnage aléatoire stratifié. Leur pression artérielle, poids et hauteurs ont été prises à l'aide de méthodes normalisées et sociodémographiques données ont été obtenues en utilisant un semistructurées prétesté questionnaire.

RÉSULTATS: La pression artérielle a augmenté avec l'âge avec des hommes ayant des valeurs plus élevées. Les autres déterminants majeurs de sang pression ont été poids, taille, indice de masse corporelle, niveau d'activité physique activité et des parents statut socio-économique $(p<0,05)$. Aucun relation a été établie entre ces déterminants que ainsi que les habitudes alimentaires et le statut socioéconomique des parents $(P>0,05)$. Les adolescentes avec les parents dans le socio-économiques inférieures les classes ont été significativement plus élevé systolique et diastolique la pression artérielle $(p<0,05)$. En revanche, les parents socio-économiques statut montré aucune relation significative avec artérielle systolique pression et la pression artérielle diastolique chez les mâles $(p<0,05)$. Le prévalence de l'hypertension artérielle était plus élevée chez les femmes que chez les hommes.

CONCLUSION: Le faible statut socio-économique des parents semblent être associée à une pression artérielle plus élevée occasionnels en particulier dans les femmes côtières adolescents nigérians. déterminants traditionnels ne semble pas jouer un rôle important. Le stress psychologique découlant de facteurs de stress environnementaux et économiques peuvent être responsables. WAJM 2009; 29 (3): 146152.

Mots-clés: statut socio-économique des parents, la pression artérielle, adolescents, le Nigéria

Departments of $*$ Medicine, Paediatrics, University of Calabar, Calabar, Nigeria.

Correspondence: Dr Victor O. Ansa, Department of Medicine, University of Calabar, CRS, Nigeria. E-mail: vic_ansa@yahoo.com 


\section{INTRODUCTION}

Hypertension is rapidly becoming a major public health problem and has been identified as one of the leading causes of cardiovascular disease as well as premature mortality in the world. ${ }^{1,2}$ A vast majority of cases have no known aetiology. Emerging data suggest that essential hypertension also occurs in the young and as a result, assessment and management of blood pressure in childhood and adolescence is strongly recommended to ensure improved cardiovascular health in adulthood. ${ }^{3}$ Socioeconomic status has profound effect on physical health. Several studies have shown that low parental socioeconomic status is associated with higher casual adolescent blood pressure and hypertension. ${ }^{4-7}$ Though the exact mechanisms remain unclear, residence in poor neighborhoods where environmental and economic stressors abound may be contributory. These stressors have been found to influence casual blood pressure in adolescents. ${ }^{8-10}$

Low parental socioeconomic status has also been associated with foetal undernutrition which results in permanent alteration in the regulatory systems involved in the long term control of arterial pressure. It also increases susceptibility to cardiovascular disease in adult life. ${ }^{11}$ Studies have further shown that this foetal under nutrition makes a baby vulnerable to stress that accompanies poor living conditions. Raised blood pressure in adolescents of poor socioeconomic background may be a persisting consequence of vulnerability to stress in prenatal, perinatal and postnatal life. ${ }^{12,13}$ Blood pressure tracking confirms that persistent elevation of blood pressure in childhood and adolescence is related to hypertension in adulthood. ${ }^{14,15}$

This study wass therefore aimed at evaluating the relation between of parental socio-economic status (SES) and casual blood pressure of Nigerian adolescents.

\section{SUBJECTS, MATERIALS, AND METHODS}

One thousand and eight adolescents aged 10 to 17 years of two randomly selected secondary schools from two different socioeconomic areas of Calabar metropolis in Cross River State of Nigeria formed the subjects for the study. One of the schools was attended by adolescents of low social class and a few from the middle class and located in the poorer area of the city. The other was attended by upper and middle class adolescents and located in the municipal area of the city. The other major criterion used to categorise the schools was the difference in school fees paid. The average fees paid per term for the schools attended by children from the lower socioeconomics classes was three thousand Nigerian naira only. In the schools attended by children from the higher social classes the fees per term was 45 thousand Nigerian naira and higher. Both schools were selected by balloting from the group of schools in the designated socioeconomic areas. Ages were those of the last birthday and corresponded to school records.

Subjects were selected by stratified random sampling. Each school hads six classes and each class had several streams. Six streams per class were randomly selected by balloting and 30 subjects were then randomly selected from the streams earlier chosen using the table of random numbers ensuring gender near equality. Socio demographic data which included age, sex, father's occupation, mothers' educational status as well as parents' marital status were obtained from the subjects using a semistructured questionnaire. Involvement in physical activity was also documented as subjects self reported the frequency and duration of physical activity they engaged in daily. Physical activity for the adolescents typically included walking to school, informal outdoor games like football, running errands on foot or bicycle and fetching water for domestic use. Subjects who engaged in at least 60 minutes of physical activity a day for at least three days were considered physically active. This is in conformity with the current recommendations for the assessment of physical activity in youth. ${ }^{16}$ Dietary intake was measured using a 24-hour food recall administered to all subjects. Respondents reported all foods consumed during the previous 24 hours (midnight to the following midnight). The 24-h recall has been used by US Department of Agriculture (USDA) for decades and validated by various studies. ${ }^{17,18}$ Its use is easier in an environment like ours where there is little day to day variation in the diet and types of food is limited.

All subjects had their blood pressure measured in the morning by the authors (all doctors) in the sitting position from the right arm after five minutes rest using Accuson ${ }^{\circledR}$ mercury sphygmomanometer with cuff of appropriate sizes. The appropriate cuff was that which had a bladder length of $80 \%$ and width that was a least $40 \%$ of the subject's arm circumference. Phases 1 and V Korotkoff's sounds were used as systolic and diastolic values respectively. ${ }^{19}$ Two measurements were taken from each subject to the nearest $2 \mathrm{mmHg}$ at five minutes interval and the mean calculated and used for analysis. Elevated blood pressure was defined as systolic and/or diastolic blood pressure $\geq 95^{\text {th }}$ percentile for age and sex as recommended by the Fourth Report on the diagnosis, evaluation and treatment of high blood pressure in children and adolescents. $^{3}$

Anthropometric measurements were taken according to the methods described by Paynter and Parkin. ${ }^{20}$ Height was measured with subjects standing barefoot using an erect metre rule placed against a perpendicular wall. The subjects stood erect, barefooted heels together against the bottom of the wall with the buttocks, shoulder and head touching the wall with the chin raised. They were told to look straight ahead, take a deep breath, and make themselves as tall as they could. A head piece was then made to rest on the head of the subject and held firmly to the wall at right angles and the subject was asked to move from under the head piece. The height was read from under the head piece on the calibrated metre rule placed against the perpendicular wall to the nearest 0.1 centimetre. The height was confirmed by a second researcher.

Weight was measured using a calibrated bathroom scale. The bathroom scale has been recommended for use in older children and adolescents where the beam scale is not available. ${ }^{21}$ Subjects 
were asked to stand on the weighing scale without shoes and wearing light clothes. They remained upright on the scale with upper limbs to the sides of the body while the weight was read to the nearest $0.1 \mathrm{~kg}$ and recorded. Each measurement was followed by the adjustment of the scale to the zero mark. A standard $20 \mathrm{~kg}$ weight was used to confirm the weight on the measuring scale after every 20 th subject to ensure precision. The weighing scale was recalibrated after each measurement. The Body mass Index (BMI) calculated using the formula

BMI = Weight $(\mathrm{kg}) /$ Height $\left(\mathrm{m}^{2}\right)$

The socioeconomic status (SES) of the family was assessed using the father's occupation and the maternal educational attainment as proposed by Olusanya et $a l .{ }^{22}$ This method stratifies SES into five classes I to V. Class I are in the upper class and classes II and III are middle class while classes IV and V are low socio economic classes. The father's occupation has a cumulative score of 3 while the mothers' educational attainment has a cumulative score of 2 . The total score places the subjects in the respective classes. For example class $1=$ total score of 1 , class $2=$ total score of 2 and so on. Father's occupation: AProfessionals, Top civil servants, politicians, businessmen, Score 1. BMiddle level bureaucrats, skilled artisans and well to do traders, Score 2. CUnskilled workers and those whose income is at or below the national minimum wage, Score 3. Mother's Educational Attainment: A - Tertiary Education - University, Polytechnic (HND), Score 0. B - Secondary Education - Secondary school, College of Education, Ordinary Diploma, Score 1. C-
Primary Education or no schooling, Score 2. This classification is very relevant in developing countries like Nigeria where most mothers are uneducated. Mother's education has been shown by studies to be positively associated with health care knowledge and heath care practice within the family irrespective of family income. ${ }^{17-19}$

\section{Ethical Considerations}

Informed consent was obtained from the parents, Principals of participating schools and the study

Table 1: Socio-demographic Characteristics of Subjects

\begin{tabular}{lrrr}
\hline \multirow{2}{*}{$\begin{array}{l}\text { Age } \\
\text { years })\end{array}$} & \multicolumn{3}{c}{ Number $(\%)$} \\
\cline { 2 - 4 } & Male & Female & \multicolumn{1}{c}{ Total } \\
\hline 10 & $24(5.0)$ & $38(7.7)$ & $62(6.4)$ \\
11 & $48(10.2)$ & $86(17.5)$ & $134(13.9)$ \\
12 & $81(17.2)$ & $86(17.5)$ & $167(17.3)$ \\
13 & $81(17.2)$ & $64(13.0)$ & $145(15.0)$ \\
14 & $61(12.9)$ & $69(14.0)$ & $130(13.5)$ \\
15 & $72(15.3)$ & $82(16.7)$ & $154(16.0)$ \\
16 & $63(13.3)$ & $38(7.7)$ & $101(10.5)$ \\
17 & $42(8.4)$ & $29(5.9)$ & $71(7.4)$
\end{tabular}

Total 472(49.0) 492(51.0) 964(100.0)

\section{Parental social class}

$\begin{array}{lr}\text { Upper (1) } & 224(23.2) \\ \text { Middle (2\&3) } & 444(46.1) \\ \text { Lower (4 \& 5) } & 296(30.7) \\ \text { Total } & \mathbf{9 6 4 ( 1 0 0 . 0 )}\end{array}$

\begin{tabular}{lr} 
Martial status of parents & \\
Married & $914(94.8)$ \\
Separated & $9(0.9)$ \\
Single parents & $41(4.3)$ \\
\hline Total & $\mathbf{9 6 4 ( 1 0 0 . 0 )}$ \\
\hline
\end{tabular}

protocol conformed to ethical guidelines of the 1975 Declaration of Helsinki. Written consent was obtained from the parents through the chidren.Students who did not have parental consent were replaced.

\section{Statistical Analysis}

Data analysis was carried out using SPSS software Version 11 results are presented as means and percentages. Analysis of Variance (ANOVA) was used to determine differences between and within group means. Multiple Regression analysis was used to determine the association between variables. The level of statistical significance was fixed at $\mathrm{p}<$ 0.05 .

\section{RESULTS \\ Socio-demographic characteristics}

Of the 1008 subjects recruited, a total of 964 aged 10 to 17 years with complete data were included in the analysis and were made up of 472 males and 492 females. Male to female ratio was approximately 1:1.This is shown in Table 1. Two hundred and twenty-four $(23.2 \%)$ were from the upper social class (class 1), $444(46.1 \%)$ from the middle class (classes 2 and 3) while 296 (30.7\%) were from the lower socio-economic classes (classes 4 and 5). Nine hundred and fourteen $(94.8 \%)$ were from families where the parents were still married.

\section{Determinants of Blood Pressure in Adolescents}

This is shown in Table 2. Age was a significant determinant of both systolic blood pressure (SBP) and diastolic blood pressure (DBP) which were shown to

Table 2: Multiple Regression Analysis showing the Determinants of Blood Pressure in Coastal Nigerian Adolescents

\begin{tabular}{|c|c|c|c|c|c|c|c|c|c|c|c|c|}
\hline \multirow{3}{*}{ Variable } & \multicolumn{4}{|c|}{ Systolic Blood Pressure } & & & \multicolumn{6}{|c|}{ Diastolic Blood Pressure } \\
\hline & \multicolumn{2}{|c|}{ Beta } & \multicolumn{2}{|c|}{$\mathbf{t}$} & \multicolumn{2}{|c|}{ p- value } & \multicolumn{2}{|c|}{ Beta } & \multicolumn{2}{|c|}{$\mathbf{t}$} & \multicolumn{2}{|c|}{ p-value } \\
\hline & $\mathbf{M}$ & $\mathbf{F}$ & $\mathbf{M}$ & $\mathbf{F}$ & $\mathbf{M}$ & $\mathbf{F}$ & $\mathbf{M}$ & $\mathbf{F}$ & $\mathbf{M}$ & $\mathbf{F}$ & $\mathbf{M}$ & $\mathbf{F}$ \\
\hline Age & 0.371 & 0.158 & 8.317 & 3.122 & $.000 *$ & $.002 *$ & 0.329 & 0.179 & 6.804 & 3.559 & $.000 *$ & $.000^{*}$ \\
\hline SES & 0.280 & 0.090 & 0.686 & 2.044 & .493 & $.012 *$ & 0.039 & 0.143 & 0.085 & 3.258 & 0.376 & $.001 *$ \\
\hline Phy. Activity & 0.003 & -0.051 & 0.700 & -1.243 & .944 & .215 & .009 & -.089 & -0.202 & -2.153 & .840 & $.029 *$ \\
\hline Height & 0.010 & 0.050 & -0.256 & 0.795 & .798 & .422 & -0.022 & .006 & -0.509 & -0.092 & 611 & .927 \\
\hline Weight & 0.097 & 0.295 & 2.234 & 2.729 & $.026^{*}$ & $.003^{*}$ & -.086 & .344 & 1.833 & 3.202 & .067 & $.001 *$ \\
\hline B. M. I & 0.221 & 0.056 & 4.985 & 0.654 & $.000 *$ & .514 & 0.87 & -0.014 & 2.027 & -0.168 & $.043^{*}$ & .867 \\
\hline
\end{tabular}

BP, Blood pressure; SES, Parental socioeconomic status; Phy. Activity, Level of physical activity; BMI, Body Mass Index,

*Significant. statistically 
Table 3: Parental Socio-economic Status and Anthropometric Parameters in Coastal Nigerian Adolescents

\begin{tabular}{|c|c|c|c|c|c|c|}
\hline \multirow[t]{2}{*}{ Variable } & \multicolumn{6}{|c|}{ Social Classes } \\
\hline & 1 & 2 & 3 & 4 & 5 & p-value \\
\hline \multicolumn{7}{|c|}{ Diastolic Blood Pressure } \\
\hline Male & $64.3 \pm 9.3$ & $64.9 \pm 9.5$ & $65.4 \pm 8.8$ & $66.2 \pm 9.7$ & $18.1 \pm 10.4$ & .125 \\
\hline Female & $62.8 \pm 9.8$ & $65.5 \pm 9.8$ & $64.6 \pm 9.8$ & $66.5 \pm 9.1$ & $68.5 \pm 8.0$ & $.002 *$ \\
\hline \multicolumn{7}{|c|}{ Systolic Blood Pressure } \\
\hline Male & $102.9 \pm 12.3$ & $105.4 \pm 11.4$ & $106.2 \pm 12.4$ & $108.5 \pm 14.5$ & $107.4 \pm 12.8$ & .143 \\
\hline Female & $100.8 \pm 12.3$ & $105.7 \pm 13.2$ & $104.4 \pm 12.3$ & $103.9 \pm 11.3$ & $106.8 \pm 11.8$ & $.009 *$ \\
\hline \multicolumn{7}{|c|}{ Body Mass Index $\left(\mathrm{Kgm}^{-2}\right)$} \\
\hline Male & $18.3 \pm 3.0$ & $18.6 \pm 2.4$ & $18.1 \pm 2.2$ & $18.3 \pm 3.1$ & $18.0 \pm 1.7$ & .468 \\
\hline Female & $18.9 \pm 3.0$ & $19.6 \pm 3.6$ & $19.1 \pm 7.4$ & $19.0 \pm 2.9$ & $18.8 \pm 2.0$ & .347 \\
\hline \multicolumn{7}{|l|}{ Weight } \\
\hline Male & $46.7 \pm 12.7$ & $48.6 \pm 10.8$ & $46.0 \pm 10.4$ & $51.5 \pm 9.1$ & $46.3 \pm 10.1$ & .529 \\
\hline Female & $46.7 \pm 10.0$ & $48.1 \pm 11.1$ & $45.6 \pm 8.6$ & $45.2 \pm 9.1$ & $45.2 \pm 9.8$ & .178 \\
\hline \multicolumn{7}{|l|}{ Height } \\
\hline Male & $1.58 \pm .11$ & $1.60 \pm .12$ & $1.74 \pm .12$ & $1.94 \pm .22$ & $1.58 \pm .11$ & .101 \\
\hline Female & $1.56 \pm .07$ & $1.56 \pm .08$ & $1.54 \pm 0.9$ & $1.54 \pm 1.08$ & $1.53 \pm .9 .0$ & .189 \\
\hline
\end{tabular}

$\mathbf{B P}$ is $\mathrm{mmHg}$ *Significant

Table 4: Prevalence of Elevated Blood Pressure in Coastal Nigerian Adolescents

\begin{tabular}{lccc}
\hline & \multicolumn{3}{c}{ Number $(\%)$} \\
\cline { 2 - 4 } & Male $(\mathbf{n = 4 7 2})$ & Female $(\mathbf{n = 4 9 2 )}$ & Total $(\mathbf{n = 9 6 4 )}$ \\
\hline Age group in years & & & \\
$10-11$ & $1(0.2)$ & $2(0.4)$ & $3(0.3)$ \\
$12-13$ & $2(0.4)$ & $3(0.6)$ & $5(0.5)$ \\
$14-15$ & $2(0.4)$ & $3(0.6)$ & $5(0.5)$ \\
$16-17$ & $3(0.6)$ & $2(0.4)$ & $5(0.5)$ \\
Total & $\mathbf{8}(\mathbf{1 . 6})$ & $\mathbf{1 0}(\mathbf{2 . 0})$ & $\mathbf{1 8}(\mathbf{1 . 8})$ \\
Parental Socio Economic Class & & \\
1-Upper & $2(0.4)$ & $0(0)$ & $2(0.2)$ \\
$2-$ Middle & $1(0.2)$ & $4(0.8)$ & $5(0.5)$ \\
$3-$ Middle & $1(0.2)$ & $2(0.4)$ & $3(0.3)$ \\
4- Lower & $4(0.8)$ & $1(0.2)$ & $5(0.5)$ \\
$5-$ Lower & $0(0)$ & $3(0.6)$ & $3(0.3)$ \\
\hline Total & $\mathbf{8}(\mathbf{1 . 6})$ & $\mathbf{1 0}(\mathbf{2 . 0})$ & $\mathbf{1 8}(\mathbf{1 . 8})$ \\
\hline
\end{tabular}

increase with age $(\mathrm{p}<0.05)$ (Figures 1 and 2). The parental socioeconomic status (SES) was significantly associated with SBP and DBP in females only. The lower the SES the higher the values $(\mathrm{p}<$ $0.05)$. The level of physical activity was only associated with DBP in female adolescents and was higher in the less physical active adolescents $(\mathrm{p}<0.05)$.

Body mass index (BMI) showed significant association with SBP and DBP in male adolescents only $(\mathrm{p}<0.05)$, the more the BMI the higher the blood pressure values. Weight was only a blood pressure was statistically significant only in the females $(\mathrm{p}<0.05)$. Diastolic blood pressure (DBP) was also found to be significantly associated with parental socioeconomic status (SES) (p $<0.05$ ). The lower the SES the higher the DBP. Overall, parental socioeconomic status was found to be significantly associated with both SBP and DBP only in the female adolescents. The mean BMI was not influenced by parental socioeconomic status. $(\mathrm{p}>0.05)$.

\section{Physical activity, Dietary Habits, and} Socio-economic Status.

Seventy-five percent of subjects were physically active being engaged in outdoor sporting activities like football, table tennis, running errands and fetching water for domestic use. No significant difference was observed between the social classes as regards physical activity $(\mathrm{p}>0.05)$.

Majority of the subjects $(99.7 \%)$ had diets high in carbohydrates with little fat and oils. Carbohydrates were gotten from meals like rice, bread, yams and plantain, protein from beans and bean products while vegetable oil and palm oil used in preparing soup and stew served as sources of fat. Margarines, meat and milk were sparingly consumed. No significant difference was also observed between the socioeconomic groups ( $\mathrm{p}>$ $0.05)$.

\section{Prevalence of High Blood Pressure}

This is shown in Table 4. The prevalence of high blood pressure was $1.6 \%$ in males $2.0 \%$ in females with an overall prevalence (males and females) of $1.8 \%$. Prevalence was higher in adolescents with parents in the middle and lower socioeconomic classes than those in the upper class. DBP in the females only. was not a significant determinant of the blood pressure in both sexes ( $p>0.05)$.

\section{Socio-Economic Status, Blood Pressure and Body Mass Index}

Adolescents from the lower socioeconomic classes were found to have higher systolic blood pressure (SBP) than those in the upper and middle classes. This is shown in Table 3. This association between parental socioeconomic status and adolescent systolic

\section{DISCUSSION}

In this study the determinants of blood pressure in coastal Nigerian adolescents were age, weight, body mass index (BMI), level of physical activity and parental socioeconomic status and corroborate findings from earlier studies in Nigerian adolescents from other parts of the country and else where in the world. ${ }^{5,26-29}$ 


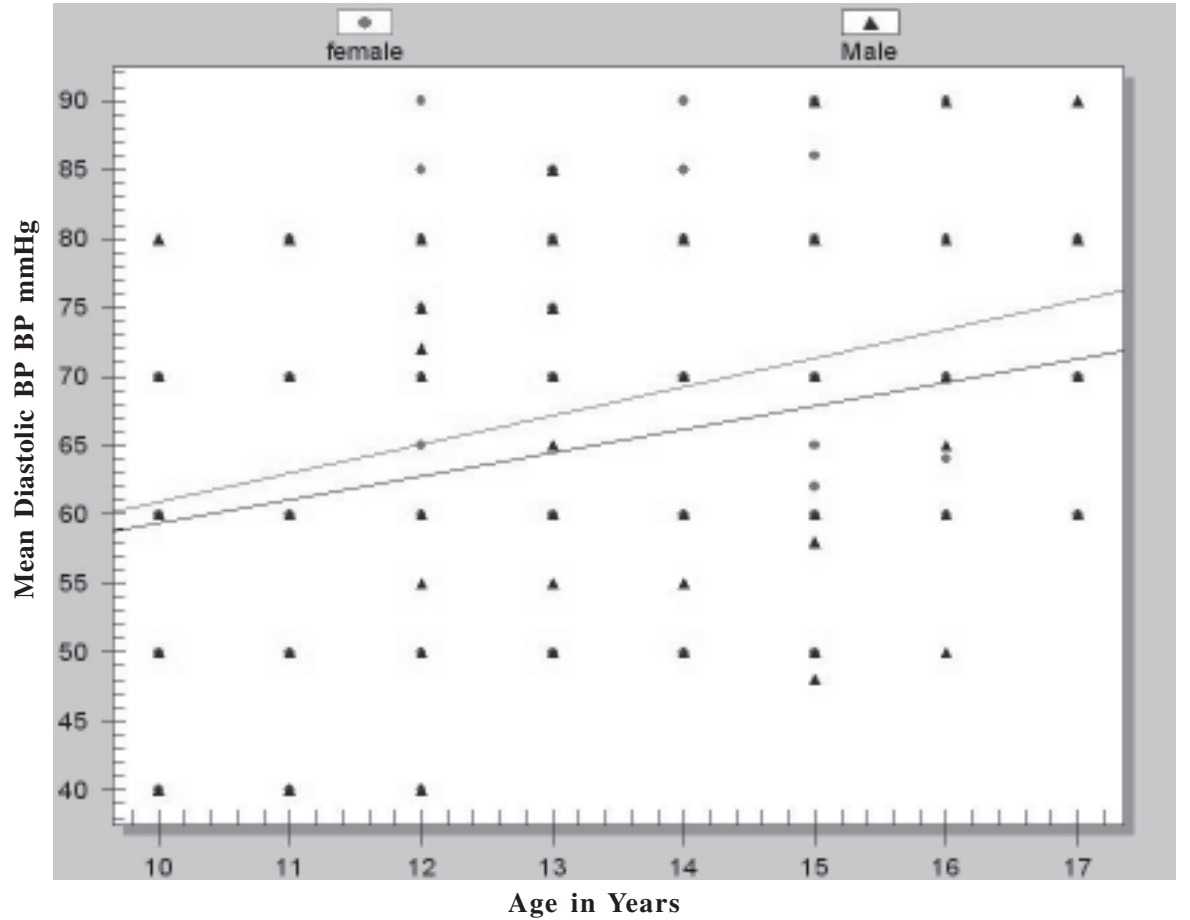

Figure 1: Scatter plot showing Diastolic Blood Pressure of Coastal Nigerian Adolescents by Age and Sex. $\bullet$ Female $\square$ Male

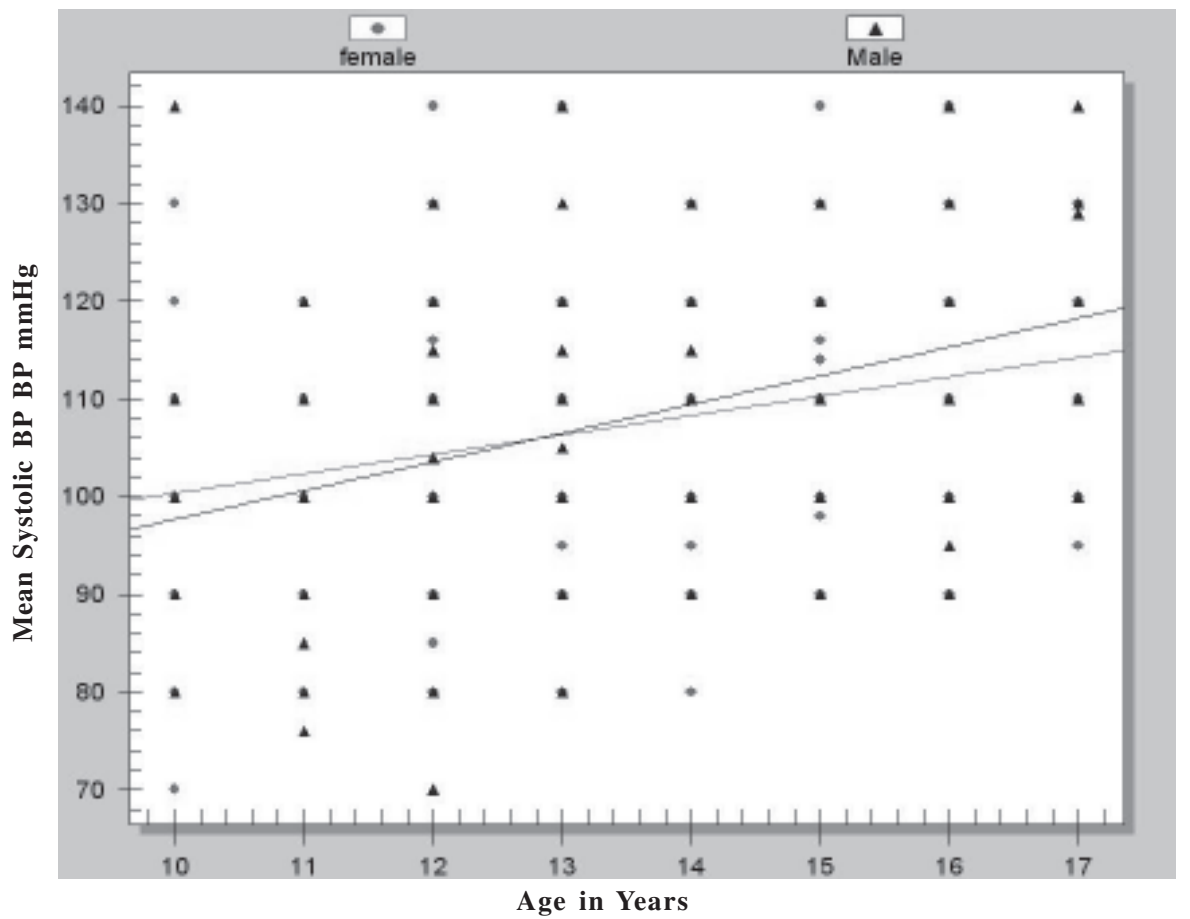

Figure 2: Scatter plot showing Systolic Blood Pressure of Coastal Nigerian Adolescents by Age and Sex $\bullet$ Female $\square$ Male

As regards the association between blood pressure in these adolescents and parental socioeconomic status (SES), the lower the SES the higher the blood pressure. This is also in keeping with findings from earlier studies in Nigeria
Ibadan. This not surprising as this study and theirs were carried out in urban centres. It has also been reported by Mvo et $a l^{33}$ that among females in the lower socioeconomic classes in the African culture, it is often desirous to be overweight as it indicates wealth and happiness. Girls in the higher social classes may adopt western beauty ideals without fatness like the Caucasian girls. Balogun et $a l^{4}$ found no association between parental socioeconomic status and blood pressure in children in Ife, Nigeria. This may be due to the fact that Ife is a semi-urban town where the socioeconomic class distinction may not be very clear and adoption of western style lifestyle at the time of the study at its early stages.

The parental SES was not found to influence the BMI of our subjects despite the fact that the females in the lower SES had higher BMI and this may be explained by the fact that their dietary habit and level of physical activity did not differ significantly across the socio-economic classes. The subjects irrespective of social class were still physically active being engaged in informal outdoor sporting activities such as football as well as running errands on foot or bicycle. Their diet was generally made up of carbohydrate with little protein and fat, thus most subjects had normal body mass index. Therefore extra calories from unhealthy dietary habits did not lead to significant weight gain. This observation has been reported in a study of adolescents from poor socioeconomic background in Nigeria. ${ }^{34,35}$ Studies from developed countries have reported higher body mass index in adolescents from low socioeconomic background which is attributed to early adoption of unhealthy dietary habits owing to lack of parental guidance and non availability of free space for physical activity like parks and walkways. ${ }^{6,9}$ The converse has been demonstrated in our study from a developing country where dietary habit is still generally healthy and adequate space is still available for significant physical activity.

Our findings suggest that the higher blood pressure in subjects of low socioeconomic background was not influenced by the traditional risk factors 
- body mass index, physical activity and dietary habit. The relationship between socioeconomic status and blood pressure in this study could have been as a result of emerging new risk factors like foetal undernutrition and psychological stress which have been found to play major roles in the pathogenesis of high blood pressure in adolescents of poor socioeconomic background. Though low maternal socioeconomic status may be associated with low birth weight and thus indirectly with filial hypertension, the pathway is however not yet clearly understood. ${ }^{36}$

Most of our subjects from lower socioeconomic classes reside in poor neighbourhoods with their parents. This is because as one moves down the socioeconomic ladder, residential choices become more limited. These neighbourhoods are usually characterized by high level of environmental stressors such as noise, overcrowding and violence. There is also economic stress from chronic poverty. These stressors usually lead to structural changes in the vascular wall which in turn elevate blood pressure. ${ }^{6-10}$ The finding of higher casual blood pressure in our subjects from lower parental socioeconomic background may be due to the influences of these stressors. The probable effect of environmental stressors on the blood pressure of adolescents of African descent has been well highlighted. ${ }^{30-32}$

The overall prevalence of elevated blood pressure in both sexes was $1.8 \%$ with males having a prevalence of $1.6 \%$ and females $2.0 \%$. These values though lower than those in the literature are still within the range usually reported. Though majority of the subjects had parents in the middle and lower socioeconomic classes, the blood pressure elevation in these groups of adolescents cannot be attributed solely to parental socioeconomic status. This is because other factors that may have contributed to the elevation were not sought in this study. These have been listed as constituting our limitations.

This study has some limitations. Like many population based studies, our blood pressure reading was based on an average of two measurements at a single visit. A more precise estimate of blood pressure would have been obtained by multiple measurements during several visits. Family history of hypertension, obesity and diabetes mellitus were not obtained. An enquiry about tobacco use was also not made. Dietary data was collected for one day only. Accurate dietary intake of individual subjects may not have been assessed precisely as a single dietary recalls are known to be sometimes flawed.

We conclude that Nigerian adolescents of poor parental socioeconomic background have higher casual blood pressure. Limited access to health care, poor housing and food restriction is common in this socioeconomic group. Exposure to environmental and economic stressors which result from these have been implicated. Strategies to combat poverty and improve on the socioeconomic status of the populace should be put in place. Longitudinal studies should be carried out to follow up these adolescents to adulthood.

\section{ACKNOWLEDGEMENTS}

We thank the Parents, Principals, Teachers and Students of participating schools for their cooperation and support during the study. We also express our gratitude to Dr Ekuri for helping with the statistical analysis.

\section{REFERENCES}

1. Murray CJ, Lopez AD - Mortality by cause for eight regions of the World: Global Burden of Disease Study. Lancet 1997; 349: 1269-1276.

2. Edwards R, Unwin N, Mugusi F, Whiting D, Rashid S, Kissima J, Aspray T.J. Alberti KG - Hypertension prevalence and care in an urban and rural area of Tanzania. J Hypertens 2000; 18: 145-52.

3. National High Blood Pressure Education Program Working Group on High Blood Pressure in children and adolescent. The Fourth report on the diagnosis, evaluation and treatment of high blood press on children and adolescent. Paediatrics 2004; 114: 55576.

4. Balogun SA, Obajuluwa VA, Olaogun MO, Abereoji, OK, Oyemi AY, Adeodu OO, Balogun MO. Influence of parental socioeconomic status on casual blood pressures of Nigerian school children. Int J Cardiology 1990; 29: 63-9.
5. Akinkugbe FM, Akinwolere AO, Kayode CM. Blood pressure pattern in Nigeria adolescents. West Afr Med J 1999; 18: 196-202.

6. Norman BA, Armstead AC. Towards understanding the association of socioeconomic status and health: a new challenge for the Biophysical approach. Psychosomatic Medicine 1995, 57: 213 225.

7. Kaplan GA, Keil JE. Socioeconomic factors and cardiovascular disease: a review of the literature. Circulation 1993; 88: 1973-1998.

8. Wilson D K, Kliewer W, Plybon Z, Domenic AS. Socioeconomic status and Blood Pressure Reactivity in healthy black adolescents. Hypertension 2000; 35: 496.

9. Chen E, Paterson LQ. Neighborhood, family and subjective socioeconomic status: How do they relate to adolescent health? Health Psychology. 2006; 25: 704-714.

10. Matthew KA, Kiefe CI, Lewis CE, Lin K, Sidney S, Yunis C. Socioeconomic trajectories and incident hypertension is a biracial cohort of young adults. Hypertension 2002; 39: 772-776.

11. Alexander BT. Divergent origins of slow foetal growth: relevance to Adult Cardiovascular disease. Hypertension 2007; 50: 465-466.

12. Barker DJP,Bagby SP,Hanson MA. Mechanisms of disease: in utero programming in the pathogenesis of hypertension. Nat Clin Nephrol. 2006; 2: 700-707.

13. Barker DJP,Osmond C,Forsen TJ, Kajantie JG. Maternal and Social origins of Hypertension. Hypertension 2007; 50: $565-571$.

14. Lauer RM, Clarke WR. Childhood risk factors for high adult blood pressure: the Muscatine study. Paediatrics 1989; 84: 633-41.

15. Bao W, Threefoot S A, Srivivasan SR, Berenson G .Essential hypertension predicted by tracking of elevated blood pressure from childhood to adulthood: the Bogalusa Heart Study. Am $J$ Hypertens. 1998; 8: 657-65.

16. Prochaska JJ, Sallis JF, Long BA. A physical activity screening measure for use with adolescents in primary care. Arch Peadtr Adolesc Med. 2001; 155: 559

17. Ahluwalia N,Lamni-Keefe eCJ. Estimating nutrient intake of older adults: Component variation and the effect of varying the number of 24-h recalls. Am Diet Assoc 1991; 91:14389. 
18. Mirmiran P,Azadbakht L,Esmaillzadeh A, Azizi F. Dietary diversity score in adolescents- a good indication of the nutritional adequacy of diets: Tehran Lipid and Glucose study. Asia Pacific J Clin Nutr 2004; 13: 56-60.

19. Pickering TG, Hall JE, Appel LJ, Falkner BE, Graves J, Hill MN et al. Recommendation for blood pressure measurements in human and experimental animals. Part 1: blood pressure in humans: statement for Professionals from the subcommittee of Professional and Public Education of AHA Council on HBP. Hypertension 2005; 45: 142-61.

20. Paynter AS, Parkin M. Growth in Childhood In: Standfield P, Brueton M, Parkin M, Waterston T (eds). Diseases of Children in tropics and subtropics: London. Edward Arnold publishers; 1991. p. 254-270.

21. Kow F, Giessler C, Balasubramanian. Are International anthropometric standards appropriate for developing countries? J Trop Peadtr 1991; 37: 3744.

22. Olusanya O,Okpere EE,Ezimokhai M.The impotance of socioeconomic class in voluntary fertility in developing countries. West Afr Med J 1985; 4: 2057.

23. Otta M. Impact of maternal education on the health of the child. Journal of Family Welfare. 1992; 38: 18-24.

24. Bicego GT, Boerma JT. Maternal education and child survival: A comparative study of survey data from 17 countries. Social Science and Medicine 1993; 36: 1207-1277.
25. Alaka MB,Stephenson R. Low levels of maternal education and proximate determinants of childhood mortality: a little learning is not a dangerous thing. Social Science and Medicine 2005; 60: 2011-2023.

26. Ansa VO, Odigwe CO, Ekanem EE. Pattern of blood pressure in urban Nigerian adolescents-Experience from South-eastern Nigeria. Global Journal of Medical Sciences 2002; 1: 1-6.

27. Ejike ECC,Ugwu CE,Ezeanyika LUS, Olayemi AT. Blood pressure pattern in relation to geographic area of residences: a cross sectional study of adolescents in Kogi State, Nigeria. BMC Public Health 2008; 8: 411.

28. Menard SW, Park MK, Scholfield J. The San Antonio Children's blood pressure study: Anthropometric Findings. Clin Exc Nur Prac 1998; 4: 19-27.

29. Rosner B,Prineas R,Daniels SR. Blood pressure differences between blacks and Whites in relation to body size among US children and adolescents. Am J Epidemiology 2000; 151: 1007-1018.

30. Coto V, Lucariello M, Cocozea, Oliviero $\mathrm{U}$, Cacciatore $\mathrm{L}-$ Socioeconomic status and hypertension in children of two state schools in Naples Italy: preliminary findings. European $J$ of Epidemiology 1987; 3: 288-294.

31. Barnes VA, Trenber FA, Muscate L, Turner JP, Davis H, Strong WB.Ethnicity and socioeconomic status: Impact of rest on cardiovascular activity at rest and during stress in youth with a family history of hypertension. Ethnicity and Disease 2000; 10: 4-16.
32. Longo-Mbenza B, Liukoki E, KabunguM'Buyamba JR. Nutritional status, socioeconnmic status, heart rate and blood pressure in African school children and adolescents. Int J Cardiol 2007; 121: 171-177.

33. Mvo Z,Dick J,Steyn K. Perceptions of overweight in African women about acceptable body size of women and children. Curations 1999; 22: 27-31.

34. Ukegbu PO, Onimawo IA, Ukegbu AU. Nutritional Status and Energy Intake of Adolescents in Umuahia urban, Nigeria. Pakistan Journal of Nutrition 2007; 6: 641-643.

35. Ben-Bassey UP, Oduwole AO, Ogundipe OO. Prevalence of overweight and obesity in Eti-Osa LGA, Lagos, Nigeria. Obesity Review 2007; 8: $475-479$.

36. Mika K, Lawlor DA, Smith GD, Keltikanga JL, Elovainio M, Vehta J. et al. Early socioeconomic position and blood pressure in childhood and adulthood: The Cardiovascular risk in Young Finns study. Hypertension 2006; 47: 39-44.

37. Adedoyin OT, Adeniyi A. Prevention of hypertension in children in the tropics. African Health J 2001; 23: 1618.

38. Odey F, Anah M, Ansa V, Ogbeche M, Meremikwu M, Ekanem E. Prehypertension and Hypertension in apparently healthy adolescents in Calabar, Nigeria. Global Journal of Community Medicine 2008; 2: 1320. 